\title{
A Plea for Education: Keynote Address to the Conference of Commandants, Sofia, Bulgaria, March 2004
}

\section{Dominique Moisi *}

First, the fact that we are in Bulgaria today on the eve of NATO enlargement and on the eve of EU enlargement (which will not directly concern Bulgaria tomorrow, but will include Bulgaria in as short a time as possible) is probably the only good news we see in the world today. I have been for the last two years a professor at the College of Europe in Natolin, close to Warsaw, at the request of Jacques Delors and Bronislav Geremek, the former Polish Minister of Foreign Affairs. I have the privilege of having 120 post-graduate students - 50 percent of them coming from the "New Europe"-and I can see in their eyes their happiness to have been born at that time, in that place. The privilege of late birth, if you want. It is in their eyes that I find the only hopeful signs in the world today. I am very happy to be the guest of the Rakovski College here in Sofia, and I want to thank you very much for your hospitality.

Let me move on to less happy news. A little more than a week ago, on March 11, we realized in Europe that we too were at war. What was expressed after September 11 - "we are all Americans"-was also spontaneously, emotionally expressed after March 11. We proclaimed, "We are all Spaniards," and we deeply felt it, not only out of sympathy for a great European country but because we knew inside ourselves that we could be next. This was a threat on our civilization. It was a strike at our essence, and not at our performance. Madrid had been struck not because of the position of the Spanish Government on the war in Iraq, but simply because Spain is a liberal democracy. And just to confirm that position, there were threats made against France, before and after the event, supposedly because we have imposed a law regarding the Muslim veil.

We are, more than ever, in the same boat, facing the same threat. And yet, we also know this: divisions between Europe and America seem to continue, even after March 11,2004 . Immediately after the event, you saw in the American papers a flurry of articles denouncing the so-called "axis of appeasement," to condemn the "Munichois" attitude of the new Spanish government. Two days ago, you had demonstrations in the streets of Europe against the war in Iraq on the first anniversary of the beginning of the war, denouncing all terrorism, which means equating Bush and Bin Laden in the same denunciation.

How can this be taking place in front of us? By the end of the day-and this is the question I want to raise to you-How were we united during the decades of the Cold War when the threat was, so to speak, coming from within ourselves? Because the communist ideology was, after all, devised by Western European intellectuals, and Russia (or at least half of it) was part of Europe.

* Professor Dominique Moisi is a senior advisor at France's Institute of International Relations in Paris. 
How can we be divided today when the threat comes from outside of us, from extremist groups, which may have been influenced by the anarchists or the nihilists of late nineteenth-century Europe but are nonetheless from a different culture, a different faith, a different world? You cannot understand them without making reference to their culture, their religion, even if what they do is an absolute violation of the principles of Islam.

Yesterday, we could stand united against the Soviet Union. Today, we find ourselves no longer able to stand united against terrorism. This is a mystery, which I would like to try to understand with you, and try to transcend. We have moved in the last ten years from the clarity of the Cold War to the complexity of the present age. In fact, if you want to define the world in which we live today, you would probably use three key terms: complexity, vulnerability, and identity fragmentation.

Our world is the product of the encounter between two dates and one process. Those two dates are November 9, 1989, the fall of the Berlin Wall; and September 11, 2001, the fall of the World Trade Center in Manhattan. The process is one of globalization. In fact, I do believe that September 11 was just the dark side of globalization, revealing to us that we were not only influenced by the free flow of goods but also, unfortunately, by the free flow of evil. In this complex world, you have new phenomena, which I would describe in the following manner: Never in the history of humanity have so few had the ability to inflict so much damage on so many. This is the absolute reversal of the famous "Churchill formula" at the time of the Battle of Britain: Never was so much owed by so many to so few. It is a direct consequence of the huge gap between the progress of technology and the non-progress, if not regression, of human morality. This is something that we have to confront, together with the fact that we live in an interdependent global united world. There is no place to hide; no place to go that is safe. In that world, psychological factors become more important than ever.

There has been, in recent history, huge inequality between the very rich and the very poor, but the very poor did not know all the very rich. Today they do know them, and they may feel angry. They may feel humiliation and frustration, which leads to one last and essential factor, which is fragmentation. The more united we are (or we appear to be), the more we emphasize to those who feel cut off from the rest of the world just how removed they are.

It is this sense of fragmentation, of separation from the march of progress, that motivated the terrorists of September 11 to focus not on what America did but on what America is. It was a denunciation of the conscience of the United States, not only on its actions, and to a large extent this ends up being in my mind the most significant factor of these events, because I think we are facing the most important threat to our common future at a time when we are most divided. This is something that we have to fight. We have to fight it through an understanding of what the reasons for these divisions are, and through a definition of the means we can find to transcend them.

In the case of Europe, I think we have to change because, at the end of the day, we no longer know what we are. Confronted with the challenge of enlargement; with the challenge of institutional reform; with the challenge of forging a new collective diplo- 
matic stance for twenty-five nations today, twenty-seven tomorrow; with the challenge of demography, which is appearing to make us an aging continent; and with the challenge of no longer being believers in the European project, Europe is in the midst of its deepest identity crisis in decades. Europe no longer knows her geography. We do not know where we end. And not knowing where we end, we do not know where we are. Are we a Christian Republic club? What about the Turkish candidacy which, in the context I have been describing, is probably one of the most important ways to answer the threat of radical Islam? If there is one country in the world whose membership in Europe would be proof that you can find a modern, democratic, secular Islam, it is Turkey.

Europeans have to decide which is more dangerous for them - to say "no" to Turkey, with the risk of pushing them back into the Eastern world, so to speak; or to say "yes" to Turkey and integrate 70 million Muslims into Europe in a nation that shares borders with Syria, Iraq, and other countries.

In Europe, we also no longer know what we really want to be in an institutional sense. Diplomatically, there is a deep division between those who are supporting Washington and those who are opposing Washington. I think that the distinction, which was aggressively made by Donald Rumsfeld, between the "new Europe" and "old Europe" does not, to my mind, correspond at all to reality.

Old Europe is precisely the Europe that has not made reconciliation with itself. Old Europe can be seen in the Balkans. Old Europe can be seen in the relations between Serbs and Kosovars.

New Europe is the Europe of reconciliation between France and Germany. This is the new Europe, in my mind, and to make a distinction between old Europe versus new Europe based only on the respective groups' attitude towards Washington is simply unfair and unrepresentative of the situation in Europe. Old Europe is the Europe of war. New Europe is the Europe of reconciliation.

Demographically, Europeans do not feel secure, because they know they are an aging continent and they fear that the future may not be on their side, which may make them more nervous about the changing realities of the world. And, at the end of the day, you also have in Europe the sense that the European project has become a reality but it has ceased to be a dream, and the reality is something that we have to live with. In fact, I am looking forward to enlargement with great hope when I see the new faces, the new commissars coming from ten new countries, gathering in Brussels around Mr. Prodi. I see anger, optimism, and dynamism in their eyes; maybe they can resurrect in us a sense of a mission in Europe. I do welcome them very warmly, as I will welcome Bulgaria and Romania tomorrow into the European Union.

On the other side of the Atlantic, I do not think the United States is in the midst of an identity crisis, but it is in the midst of an identity change. The America that has emerged from the end of the Cold War is a different America demographically, geographically, and ideologically. You have to add the interaction between those deep structural changes and the events of September 11. It is the combination between structural changes in the U.S. and the fact that the events of September 11 took place at 
a time when a particular administration was in power in Washington that explains why we are facing a new America.

In a few years from now, more than one American out of two will not have English as his first language. This has huge consequences for the relationship between Europe and the United States. Suddenly, Americans will not consider Europe to be a direct source of heritage on fundamental issues such as religion, the place of God in society, and in one's own definition of self. In terms of patriotism, America is largely on a different planet from Europe. In terms of military strength, we are no longer in the same category, but this has been true for a very long period of time. What is more significant is that we belong more and more to an increasingly different culture. This is why some analysts would speak of an American West facing a European West.

In this context, what should we do knowing that we are facing a terrible threat to our civilization? I would say that we need to do three things.

First and foremost, we should remain what we are. This means that these attacks on our democratic system demand, more than ever, that we respond to them with democracy. The first answer for us is to be even more democratic than we are. The enemy wants us to close our system, to violate those democratic principles of which we are so proud. The answer to violence is democracy. This is why I was annoyed when, somehow, some people on both sides of the Atlantic denounced the results of the Spanish election as if they were a victory for Al-Qaeda, whereas I believe they were a victory for democracy. At the end of the day, yes - there was a shift of the majority in Spain, but one which was linked largely to the failure of the Spanish government to come to its people to say, "Well, it may be Al-Qaeda, but it is not because of the war in Iraq. It is because we are a liberal democracy and we are to fight it together."

The subway bombings may not have changed the results of the election but, at some point in those two decisive days in Madrid, the Spanish government gave the impression of manipulating the news, and it paid a heavy price for that.

Beyond remaining what we are, the second imperative in my mind is to learn about each other. Intolerance is based on ignorance. Americans no longer learn European languages. No longer are they interested in European culture or history. The number of programs of European Studies in American universities has dramatically fallen. The number of Americans learning French or German is greatly diminishing. In our global age, there is no interest; because there is no interest, there is no knowledge; and because there is no knowledge, there is no understanding. It is crucial for the future of trans-Atlantic relations that there should be a renewal of European studies in America, and vice versa. It is crucial in a country like mine, France, that there should be greater emphasis on the actual, objective study of the U.S. In fact, there are nearly no chairs in American Studies in French universities, because we believe that we do not have to learn about it; it seems so familiar that somehow we all believe we are experts in America. This is not the case. As much as we have to learn about each other, the "relative other," we must learn also about the "absolute other," and we do not. The number of people who have read the Koran, the number of people who have an understanding of the Arab world - of its greatness in many periods of history — is shrinking. 
The third thing is so obvious that I can cover it quickly: we have to unite. The scene of Europeans and Americans disagreeing with each other on the aftermath of what happened in Madrid seems to me like two irresponsible school children arguing about the "sex of angels" on the eve of the fall of Constantinople. We no longer have the opportunity, the luxury, of doing what we are doing, which is insulting each other and using stereotypes that make no sense, but are simply used as a way to destroy the other in the argument. The way Americans sometimes describe Europeans does not take into account the reality of Europe. The way Americans have used Europe's past to disqualify the current European stance by saying that Europe was not only " $\mathrm{Mu}$ nichois" but probably "Vichyssoise" is, to my mind, unnecessary and not constructive. In the case of Europe, there has also been a lack of understanding of the impact of September 11 on the American psyche. We declared that we were all Americans, but deep down we have failed to understand what it meant for a psychologically self-sufficient continent suddenly to find violence, not on its doorstep, but at its very heart. We missed a huge opportunity after September 11, and I do hope we will seize the opportunity now because, unfortunately, this is simply another step. It is not the end of the story, but one episode in the tragic story.

In fact, I want to mention something before moving to my next point. We are all in the West slowly starting to become like Israelis - waking up in the morning not knowing what will happen to us in the afternoon. This is slowly affecting our psyche.

After discussing what to do, I will move onto the third portion of my remarks, which is: Where to act? Where to act, I would say, would very probably be first in the Middle East, but the Middle East in my mind goes beyond Iraq. Iraq was, and remains, a difficult and complex case. As a Frenchman, I was a rather lonely voice in my country when supporting the war in Iraq. I supported it, however, with the greatest of reservations, because somehow I was unconvinced by the American argument, but I rallied to the American conclusion that Saddam Hussein should be ousted. I was convinced by the French argument about the defense of international law, but unconvinced by the French conclusion because, if we had followed the French, Saddam Hussein would probably still be in power today. At the time, I felt that the Americans would win the war very quickly, and could lose the peace very easily too.

Today we must act upon three convictions.

The first one is that an American defeat in Iraq is a defeat for the West at large. This is the last thing we should wish for, whatever our feelings were about that war. It is going to be very difficult, and we cannot base all of our political judgment on the evolution of the situation in Iraq. At the end of the day, there is Afghanistan, which is still violent and where order has not been restored. There are Al-Qaeda leaders hiding somewhere between Afghanistan and Pakistan who have to be seized. There is also, of course, at the emotional core of the problem, the Israeli-Palestinian conflict. Early this morning, Israeli helicopters killed Sheikh Hassein. There is bound to be an explosion of violence in the days to come. This cannot go on. At some point, the international community has to intervene decisively to put an end to that terrible war.

When asked to convince the Palestinians that they have to accept the existence of 
Israel as a long-term reality, as a permanent fixture of the Middle East situation-and one has to convince the Israelis that they have to exist within boundaries that have been accepted by the international community - I recommended NATO to play the role of peace-keepers, to take a position in Jerusalem between Israelis and Palestinians, to accompany a peace settlement and to make that peace settlement a more secure probability. I think we have to realize the emotional centrality of the Middle East for all of us.

There are other issues than the Middle East, and what has happened in the last week in Kosovo should give us, at the same time, a combination of despair and hope. Despair, because it shows that ethnic hatreds in all periods of time are so deep, so rooted in the emotions of man, they are very difficult to get rid of. Despair was mounting in Kosovo because there was no evident political solution. The parliament that was elected in Kosovo had no power. We had hinted to the Kosovar leaders that we would give them independence, and no independence was forthcoming. 40 to 50 percent of the people in Kosovo were unemployed. You had the perfect recipe for disaster: idleness and frustration.

At this time there is hope, because we have learned from our past mistakes. At the very moment that there are explosions in Kosovo, we send troops and reinforcements. We have learned in the Balkans that there is a direct cost of coming in too little, too late. The first war in Bosnia led to the deaths of 250,000 people. The second war in Kosovo led to the death of 10,000 people. The third war in Macedonia led to the death of 300 people. The difference between those figures is a clear reality, which is the value of intervention — quick, swift, and decisive.

We are learning, but very, very slowly. In fact, Kosovo is probably confirmation that people come to the right conclusion after they have exhausted all other alternatives.

Right now, there is (and this is something new) a slight interrogation of the future of Russia. How have we moved from too much instability in Russia in the last ten years to nearly too much stability? There is something new in Russia, which from the outside we do not fully understand - unless we understand it too well! Putin is still a mystery to us. He is the heir of Peter the Great, but he is also presenting himself as the heir of Andropov. It is not the return of Communism, it is not the return of Communists, but it is to a certain extent the return of Soviet apparatchiks at the head of the new Russia. We welcome order and stability in Russia, but not at any cost or at any price.

We want Russia in Europe, and we do not want to have to build Europe against Russia again. For the moment, both roads are open, and let us hope that the road we went down in the last ten years will still be the one we will follow in the next few years.

Which leads me to my final point, dedicated to the theme of your conference: Education. I had the honor last year of being asked by Princeton University to be part of a five-person "wise man" committee in charge of modifying and reinventing the International Studies program at Princeton. I spent time with four American deans from Columbia, Stanford, Yale, and Harvard to redefine the future of the International Studies 
curriculum. I think the conclusions we arrived at are probably meaningful for your session.

What did we say? We said that there is a trend in America today, in international relations in particular, which is very dangerous for an understanding of the world and can be described as the ascendance of a quantitative and scientific approach, leading to the de-humanization of international relations. We decided (and Princeton has followed our suggestions) that it was essential for students of international relations to have a deep knowledge of history and culture, since the roots of our present world were not reflected in prevalent theories of conflict. We are no longer operating under the basic knowledge that prevailed at the time of the Cold War, where we were focused on learning about the arms race and conflict theory. The basis for an understanding of our world, of its complexity, of its identity, and its current fragmentation lies in history and culture and, since Princeton University - thanks to its Institute for Advanced Studies - has one of the most famous pools of historians in the world, the study of international relations should benefit.

What does this mean for military schools? It means that at a time when you are moving from defense studies to security studies, you have also to move from security studies to political studies. This movement is of a dual nature and is, I think, perfectly in tune with the realities of our time. This is what you will have to integrate within your curriculum: historical studies, diplomatic studies, and cultural studies, because the essence of security rests in people interacting with each other. In fact, one has to understand the meaning of some basic keywords, like "humiliation." Humiliation in our present world is probably one of the most important words, which the U.S. and Europe must come to understand, and which people coming from the Arab-Islamic world have to understand too. This understanding requires historical studies and cultural studies.

I would like to dedicate my conclusion to return to the theme of unity that I alluded to at the beginning of my remarks.

At the end of the day, it is essential for Americans and Europeans to start their strategic thinking from two crucial points. Europeans have to realize that they are in the same boat as the United States. They cannot equate-as some of them do- the threat of Bush with the threat of Bin Laden. This could be suicidal. This would be offensive. This is intellectually and morally unacceptable. You may feel more or less at ease with the present administration, but this is not the point. In fact, the elections that are going to take place this November are probably going to be one of the most important rounds of elections in the history of the U.S. I would go as far as saying that, after the election of Lincoln in 1860 and the election of Roosevelt in 1932, the election of 2004 might represent a turning point. Not that the America of Kerry would be that different from the America of Bush diplomatically, but it would be socially and culturally a different nation. It would be an America that might slow down the process of alienation from Europe, whereas the re-election of Bush would probably tend to consolidate the cultural gap that exists between Europe and the United States. But-and this is my key point-Europeans have to simply accept that America is, whether they 
like it or not, their best and last life insurance policy. They should not consider America as a threat, whether they disagree or not with what Americans are doing.

There is a crucial lesson for the United States: in our present world, there is nothing that can be done without the United States, but there is nearly nothing that can be done by the United States alone. The Americans are right to emphasize to Europeans that the world is indeed a dangerous place, and Madrid was the proof of it. Europeans are right when they respond that the world is indeed a complex place. If the Americans want or need the help of their European partners, they cannot go on insulting them. Either you need us and you treat us accordingly, or you just say that you do not have to take care of us. You know deep down that this is not the case. So my plea is a plea for unity, a plea for education.

I think of all the things I have said today, and if I want to emphasize one, it is this: We cannot go on with this mixture of intolerance, ignorance, and disdain. The times are such that we have to transcend those natural tendencies to describe the U.S. as "Mars" and Europe as "Venus." It is neither/nor, something which we all know perfectly well. 